\title{
Serum and saliva levels of matrix metalloproteinase 3 and 9 in pharynx and larynx cancer
}

\author{
Małgorzata Polz-Dacewicz', Paweł Macieląg', Ewa Kliszczewska', Łukasz Rolniak' \\ ${ }^{1}$ Departament of Virology, Medical University of Lublin, Poland \\ Polz-Dacewicz M, Macieląg P, Kliszczewska E, Rolniak Ł. Serum and saliva levels of matrix metalloproteinase 3 and 9 in pharynx and larynx \\ cancer. J Pre-Clin Clin Res. 2017; 11(2): 106-110. doi: 10.26444/jpccr/76442
}

\begin{abstract}
Introduction and objective. Matrix metalloproteinases (MMPs) are proteolytic enzymes responsible for the decomposition of extracellular matrix elements. They play an important role during embryogenesis, wound healing, endometrial epithelial exfoliation, the formation of new blood vessels, and also during cancer development. Throat and larynx tumours are included in a large group of head and neck cancers. These tumours are characterized by a poor prognosis. Despite advances in medical science, cancer treatment is difficult and often ineffective. The aim of the study was to evaluate the level of MMP-3 and MMP-9 in the serum and saliva of patients with pharynx and larynx tumours.

Materials and method. Samples of saliva and serum were collected from 60 patients with larynx or throat cancer. Twenty patients without cancer comprised the control group. MMPs in saliva and serum were determined by the ELISA method. Results. In the study group, concentrations of MMP-3 in saliva were from $0.2-77.6 \mathrm{ng} / \mathrm{ml}$. Patients with malignant tumours had higher saliva MMP-3 levels than healthy subjects. The concentration of MMP-3 in the serum of the study group ranged from $10.9-200.00 \mathrm{ng} / \mathrm{ml}$, which was also higher than in the control group. There were no statistically significant difference in the MMP-9 level between the study and control groups (both in serum and saliva).

Conclusions. This study is another element that shows the phenomena taking place at the cellular level during oncological disease. In serum and saliva samples, higher values of MMP3 were found in patients with cancer. The increase in the concentration of this enzyme in the risk group may be used for early detection of tumour transformation and evaluation of treatment.
\end{abstract}

\section{Key words}

matrix metalloproteinases, larynx cancer, throat cancer, head and neck cancer

\section{INTRODUCTION}

Metalloproteinases are proteolytic enzymes responsible for the decomposition of extracellular matrix elements. There are more than 20 different enzymes belonging to this group although they differ slightly in structure and the substrate that decompose. The extracellular matrix is the structure that fuses the cells present in the body, creates space between them, and is the place where all kinds of growth factors, parts of dead cells and unnecessary metabolites are present. The task of MMPs is to reconstruct the matrix and degrade the proteins found there, to preserve the homeostasis of this structure. Under physiological conditions, metalloproteinase levels increase in the context of intense body growth. They were first described quite accidentally in 1962 during a tadpole research $[1,2]$. The role of MMPs during embryogenesis, wound healing, endometrial epithelial exfoliation, the formation of new blood vessels, and regeneration processes have been previously described [2,3]. As science progressed, it was noted that some MMPs are elevated in various pathological states. The negative effects were described in degenerative disease, Alzheimer's disease, atherosclerosis and aneurysm [2]. Some studies have shown an increased activity of MMPs during the onset of cancer [3]. The name of these enzymes is derived from the zinc metal ion which

Address dfor correspondence: Małgorzata Polz-Dacewicz, Departament of Virology, Medical University of Lublin, Poland

E-mail: malgorzatapolzdacewicz@umlub.pl

Received: 11 May 2017; accepted: 16 August 2017 is in the active centre of the protein. Several domains can be identified: prodomain, catalytic domain, haemopexin domain and elastic link. Metalloproteinases are released into the matrix in the form of proenzymes, produced by numerous cells, e.g. fibroblasts, leukocytes, and endothelial cells. To activate them, it is necessary to disconnect the prodomain. This process is influenced by physical factors (change in $\mathrm{pH}$, temperature), chemical compounds (glutathione, reactive oxygen species), or by reaction with active metalloproteins [3]. Regulation of the activity of these enzymes also takes place on several levels. The first is the transcription of genes, where growth factors and interleukins are able to stimulate the growth of gene expression. There are also factors that may block gene expression even after transcription (miRNA). Tissue inhibitors of metalloproteinases (TIMPs) play an important role in determining MMPs levels and their activity. These are proteins with a molecular weight of 21-34 kDa that are built from 2 domains. They block the enzymatic functions of MMPs both in vitro and in vivo $[3,4]$. In pathological conditions (e.g. malignant tumours) there is a decrease in the amount of TIMPs and the growth of some MMPs. Metalloproteinases participate in such phenomena as angiogenesis or collagen degradation, which is a fundamental component of cellular membranes and ensures matrix stability. They may also play an important role in the progression of some cancers. Their impact on tumour development has not been fully explained. It is generally accepted that during tumour growth the concentration of MMPs increases, although not for all of them (for example, 
MMP-15 levels decrease in pancreatic cancer). Often one enzyme grows while the values of others do not change [4]. The main role of metalloproteinases during tumour development is to facilitate cell proliferation, migration, apoptosis blockage and create new blood vessels. Degradation of the extracellular matrix, as well as the proteolysis of cell membranes, causes the physical barrier to tumour growth to be abolished. Cellular membranes made of collagen closely adhering to each other impede the penetration and migration of cancer cells. As a result of the degeneration of collagen fibres, this structure weakens and the penetration of tumour cells into healthy tissue becomes much easier. The extracellular matrix blocks admissions of tumour growth factors into cells, thus limiting the development of cancer. MMPs cause rarefaction of this structure and the tumour reaches more nutrients. This process stimulates the development of cancer [4]. Another way in which MMPs can contribute to cancer progression is to release growth factors from the surface of the cell membranes. There are many growth factors on the surface of biomembranes, e.g. EGF, HB-EGF, TGF-alpha. MMPs have the ability to activate them. Their stimulation can initiate the process of stimulating various pathways leading to excessive cell proliferation and their neoplastic transformation $[1,2,3]$.

Pharynx and larynx tumours are included in a large group of head and neck cancers. The most common are epithelial carcinomas, characterized by similar symptoms, the course of the disease and treatment. The problem is quite a significant issue, there are approximately 40,000 new cases diagnosed annually in the United States and about 7,000 patients die from it. In Poland in 2014, more than 6,000 new cases and 3,800 deaths were reported $[5,6]$. Pharynx and larynx tumorus are characterized by a poor prognosis, which is caused by a fairly advanced stage of the disease at the time of the diagnosis. The first symptoms of cancer, such as a cough, hoarseness are uncharacteristic. Symptoms that cause anxiety in patients (difficulties in swallowing and breathing, disorders in the articulation of words) will appear late and show a high disease progression. Despite advances in medical science, cancer treatment is difficult and often ineffective. Radiation therapy, surgical and chemotherapy are used in treatment. Depending on the clinical stage of the tumor, one or several of them are connected. Each of these therapies causes many side-effects that reduce the quality of life of patients.

There is a constant search for new medicines that can reduce mortality from those cancers. Cetuximab is a chimeric (mouse/human) monoclonal antibody that is an epidermal growth factor receptor (EGFR) inhibitor [5]. It blocks the migration and proliferation of tumour cells. However, despite such modern treatment, in many cases it is ineffective. There is also no simple screening for early detection of cancerous lesions. The early stage of cancer does not alter the biochemical parameters of the blood, nor does it change the body structure. Only specialist laryngological tests can detect changes in the epithelium. Healthy lifestyle is very important in the prevention of head and neck cancer. The two best known and the most common carcinogens are cigarette smoking and alcohol abuse $[6,7]$. Tobacco smoke contains about 100 different carcinogenic compounds (e.g. nitrosamines, formaldehyde, ammonia, hydrogen cyanide). Smoking also causes the formation of free radicals that leads to irreversible changes in the DNA of cells [6]. Alcohol damages the epithelial cells immediately after ingestion. This effect results in accelerated cell death and increased production of new cells. Increased proliferation leads to rise probability of mutation in the new cells. Failure in the recognition of a mutated cell by the immune system can lead to cancer development. Alone, ethanol does not have the capacity to damage genetic material, but as a result of biochemical changes acetaldehyde is created. This chemical compound makes point mutations in DNA and blocks the activity of enzymes responsible for repairing errors in the nucleotides [6].

\section{OBJECTIVE}

The aim of the study was to evaluate the level of MMP-3 and MMP-9 in serum and saliva of patients with throat and larynx tumours. Additionally, the impact of basic health behaviours (smoking and alcohol abuse) on the concentrations of these enzymes was determined.

\section{MATERIALS AND METHOD}

For the research, samples of saliva and serum was collected from 60 patients with larynx or throat cancer. Twenty patients without cancer comprised the control group. All the patiuents were treated in the Mazovian Specialist Hospital in Radom in 2013-2016. The Ethics Committee accepted the study protocol. Material for this research was collected prior to initiation of oncological treatment, after obtaining informed consent from patients. During the study, one patient was diagnosed with co-existing lung cancer and this person was excluded from further research (Tab. 1). In the research group, men (55:4) predominated, ranging in age from 32-89 years (average 58), people under 50 years of age accounted for $10 \%$ of the group. Most of the participants (63\%) resided in urban areas. Only $9(15 \%)$ individuals did not admit to smoking, while 32 (54\%) did not abuse cigarettes (Tab. 2).

MMPs in saliva and serum were determined by the ELISA method using kits from the CLOUD-CLONE CORP (MMP3: SEA101Hu and MMP-9: SCA553Hu) according to the manufacturer's instruction (centrifuge 1,000xg, dilution of samples: MMP-3 1:100 and MMP-9 1:200). Calibration curves

Table 1. Characteristic of the study group according to TNM and grading

\begin{tabular}{|c|c|c|}
\hline \multicolumn{2}{|c|}{ feature } & \multirow{2}{*}{$\begin{array}{l}\mathrm{N} \\
9\end{array}$} \\
\hline $\mathrm{T}$ & $\mathrm{T} 1$ & \\
\hline & $\mathrm{T} 2$ & 25 \\
\hline & T3 & 11 \\
\hline & $\mathrm{T} 4$ & 14 \\
\hline \multirow[t]{4}{*}{$\mathrm{N}$} & No & 30 \\
\hline & N1 & 12 \\
\hline & $\mathrm{N} 2$ & 13 \\
\hline & N3 & 4 \\
\hline \multirow[t]{2}{*}{$M$} & MO & 59 \\
\hline & M1 & 0 \\
\hline \multirow[t]{3}{*}{ G } & G1 & 18 \\
\hline & $\mathrm{G} 2$ & 39 \\
\hline & G3 & 2 \\
\hline
\end{tabular}


Table 2. Characteristics of the study group and the control group. Chisqare test. Statistical significance: $p<0.05$.

\begin{tabular}{|c|c|c|c|c|c|c|}
\hline \multirow{2}{*}{$\begin{array}{l}\text { Demographic features } \\
\mathrm{N}\end{array}$} & & \multicolumn{2}{|c|}{ study group } & \multicolumn{2}{|c|}{ control group } & \multirow[t]{2}{*}{$\mathrm{p}$} \\
\hline & & $\%$ & $\mathrm{~N}$ & $\%$ & & \\
\hline \multirow[t]{2}{*}{ Gender } & female & 4 & 6.68 & 4 & 20.00 & $>0.05$ \\
\hline & male & 55 & 93.22 & 16 & 80.00 & \\
\hline \multirow[t]{3}{*}{ Age } & $30-49$ & 6 & 10.17 & 4 & 20.00 & $>0.05$ \\
\hline & $50-59$ & 26 & 44.07 & 8 & 40.00 & \\
\hline & $60-99$ & 27 & 45.76 & 8 & 40.00 & \\
\hline \multirow[t]{2}{*}{ Place of residence } & city & 37 & 62.71 & 11 & 55.00 & $>0.05$ \\
\hline & village & 22 & 37.29 & 7 & 35.00 & \\
\hline \multirow[t]{2}{*}{ Smoking } & yes & 50 & 84.75 & 14 & 70.00 & $>0.05$ \\
\hline & no & 9 & 15.25 & 6 & 30.00 & \\
\hline \multirow[t]{2}{*}{ Alcohol abuse } & yes & 27 & 45.76 & 8 & 40.00 & $>0.05$ \\
\hline & no & 32 & 54.24 & 12 & 60.00 & \\
\hline
\end{tabular}

were drawn for each set of the attached standards. Absorbance was read at $450 \mathrm{~nm}$ with an Epoch (Biotek) spectrophotometer and converted to numerical values. Statistical significance was accepted as $\mathrm{p}<0.05$, a Mann-Whitney U-test was used to evaluate the statistical significance of differences between the groups. A Chi-square test was used to compare the study and the control group (Tab 2).

\section{RESULTS}

In the saliva collected in the study group, the MMP-3 results were from $0.2-77.6 \mathrm{ng} / \mathrm{ml}$, and in the control group from $0.1-3.3 \mathrm{ng} / \mathrm{ml}$. There were statistically significant differences between saliva MMP-3 concentrations in the study group compared to the control group. Patients with malignant tumours had higher saliva MMP3 values than healthy subjects $(\mathrm{p}<0.05)$. The concentration of MMP-3 in the serum of the patients in the study group ranged from 10.9-200.00 ng/ml, which was also higher than in the control group (range: $4.4-39.5 \mathrm{ng} / \mathrm{ml} ; \mathrm{p}<0.05)$. There was no correlation between serum and saliva MMP-3 levels in patients in the study group.

The serum MMP-9 values from the study group ranged from $86.2-2290.8 \mathrm{ng} / \mathrm{ml}$, concentrations of this enzyme in the control group ranged from $136.8-739.8 \mathrm{ng} / \mathrm{ml}$. Although the mean value in the study group was higher than in the control group, statistical relationships between these values were not shown. The concentration of MMP-9 in the saliva in the study group ranged from $5.4-1073.4 \mathrm{ng} / \mathrm{ml}$, while in the control group it ranged from $16.9-363.2 \mathrm{ng} / \mathrm{ml}$. The mean value for the study group was lower than in the control group. This dependence was not statistically significant. There was no correlation between serum and saliva MMP-9 levels in cancer (Tab. 3).

After analysis of demographic factors, such as gender, age, place of residence, and the level of education, the data did not show any statistically significant differences in values of MMPs in both saliva and serum. Cigarette smoking increased the value of MMP-9 in the serum of patients with cancer. Alcohol abuse caused a similar effect. Statistical dependence was not found comparing the levels of enzymes with regard to the TNM classification. By analyzing grading, a decrease was observed in the level of serum MMP-3 with a decrease in tumour histological differentiation (Tab. 4).

Table 3. Values of metalloproteinases obtained in the study in the control and control group. Mann-Whitney $\mathrm{U}$ test. Values in $\mathrm{ng} / \mathrm{ml}$

\begin{tabular}{|c|c|c|c|c|c|c|c|c|c|}
\hline & \multicolumn{4}{|c|}{ Study group } & \multicolumn{4}{|c|}{ Control group } & \multirow[t]{2}{*}{$p$} \\
\hline & mean & SD & $\min$ & $\max$ & mean & SD & $\min$ & $\max$ & \\
\hline MMP 3 saliva & 5.63 & 13.524 & 0.20 & 77.60 & 0.58 & 0.789 & 0.10 & 3.30 & $0.0001 *$ \\
\hline MMP 9 saliva & 173.29 & 196.208 & 5.40 & 1073.40 & 190.37 & 116.602 & 16.90 & 363.20 & 0.0997 \\
\hline MMP 9 serum & 498.02 & 453.724 & 86.20 & 2290.80 & 346.42 & 156.445 & 136.80 & 739.80 & 0.9237 \\
\hline
\end{tabular}

* statistically significant differences $p<0.05$

Table 4. Values of metalloproteinases obtained in the study, broken down by particular characteristics of the studied group. Statistical significance $\mathrm{p}<0.05$. Mann-Whitney $\mathrm{U}$ test. In the table are only features with statistically significant differences. Values in $\mathrm{ng} / \mathrm{ml}$

\begin{tabular}{|c|c|c|c|c|c|c|c|c|c|}
\hline \multirow[t]{3}{*}{ Feature } & & \multicolumn{4}{|c|}{ Saliva } & \multicolumn{4}{|c|}{ Serum } \\
\hline & & \multicolumn{2}{|c|}{ MMP3 } & \multicolumn{2}{|c|}{ MMP9 } & \multicolumn{2}{|c|}{ MMP3 } & \multicolumn{2}{|c|}{ MMP9 } \\
\hline & & mean & SD & mean & SD & Mean & SD & mean & SD \\
\hline \multirow{2}{*}{ Smoking } & No & 2.10 & 2.2 & 86.08 & 61.2 & 44.11 & 42.1 & 267.99 & 229.2 \\
\hline & $P$ & \multicolumn{2}{|c|}{0.354} & \multicolumn{2}{|c|}{0.090} & \multicolumn{2}{|c|}{0.686} & \multicolumn{2}{|c|}{$0.019 *$} \\
\hline \multirow[t]{3}{*}{ Alcohol abuse } & Yes & 6.21 & 13.6 & 164.34 & 225.2 & 51.74 & 46.1 & 608.16 & 504.0 \\
\hline & No & 5.15 & 13.7 & 180.84 & 171.4 & 48.80 & 48.7 & 405.12 & 390.7 \\
\hline & $\mathrm{p}$ & \multicolumn{2}{|c|}{0.521} & \multicolumn{2}{|c|}{0.265} & \multicolumn{2}{|c|}{0.473} & \multicolumn{2}{|c|}{$0.022^{*}$} \\
\hline \multirow[t]{4}{*}{ Grading } & G1 & 9.09 & 18.3 & 189.86 & 157.7 & 81.09 & 60.9 & 546.37 & 414.0 \\
\hline & $\mathrm{G} 2$ & 4.27 & 11.0 & 171.54 & 216.3 & 37.04 & 32.6 & 487.65 & 483.1 \\
\hline & G3 & 1.15 & 1.2 & 58.30 & 6.8 & 27.25 & 20.4 & 265.00 & 44.4 \\
\hline & $\mathrm{p}$ & \multicolumn{2}{|c|}{0.996} & \multicolumn{2}{|c|}{0.212} & \multicolumn{2}{|c|}{$0.013^{*}$} & \multicolumn{2}{|c|}{0.33} \\
\hline
\end{tabular}

* statistically significant differences 


\section{DISCUSSION}

Information about the function of metalloproteinases in the development of tumours is particularly desirable for the development of effective therapy and early detection of cancer. The wide spectrum of MMPs is particularly important not during cancer formation but during tumour progression and metastasis. Despite the fact that more than 50 years after the first description of these enzymes, we still do not have full knowledge of their role in each type of cancer. Regardless of similarities in the construction of these enzymes, they spread out into the other substrates. As a result of this process, there is a different role of each MMP during tumor development. For this reason, general conclusions cannot be drawn and detailed studies are required for each MMP and the particular cancer. Evaluation of MMPs in head and neck cancers has not been the subject of many studies. The incidence of MMP-3 and MMP-9 in throat and larynx tumours has not been analyzed to-date. MMP-3 as a representative of stromelysins and MMP-9 as a gelatinase representative was selected for the present study. Based on the available data, members of these groups play a significant role in the progression of cancers in other regions of the body [4].

Immunoassay methods, which include the ELISA test, are mainly used to assess the level of metalloproteinases. This method allows determination of the concentration of the enzyme in biological material of various kinds: blood (serum, plasma), tissue homogenates, saliva, cerebrospinal fluid, etc. The expression of the MMPs genes is determined by the PCR method, while the Western blot is used to evaluate the protein level. The method of gelatin zymography is used to determine the activity of these enzymes. The lack of harmonized standards for MMPs is a major problem, making it difficult to compare the results obtained between different studies. The effectiveness of the ELISA test for the determination of the MMPs value in serum has been confirmed in numerous studies. Chun-Ying et al. [8] analyzed the MMP-9 concentration and the predictive value of this enzyme in gastric cancer. Blood samples from 114 patients were tested and the activity of this enzyme was evaluated by ELISA and zymography. In both methods, they obtained higher enzyme values in cancer patients than in healthy subjects. Wilson et al. [9], in their review of the diagnostic role of MMP-9 in colorectal cancer, noted that in most studies higher values of this enzyme were obtained in people with cancer. Based on his team's findings on other studies, as one of the few authors, he proposed the upper limit of MMP-9 for people without colorectal cancer at $153 \mathrm{ng} / \mathrm{ml}$. Many studies focused on changes in MMPs for breast cancer (MMP-1, MMP-2, MMP-3, MMP-8, MMP-9). In most of the available work concerning this cancer, an increase was shown in the level of MMPs. In addition, there was a positive relationship between clinical disease progression and MMPs values. Furthermore, it is believed that some of them (e.g. MMP 2 and MMP-9) may be considered as monitoring agents for the efficacy of treatment, and a re-rise in concentration may suggest the necessity to include follow-up therapy in patients after the first-line treatment is discontinued $[10,11]$.

Another type of cancer in which an increase was found of MMPs concentrations in serum and their efficacy in the diagnosis and prognosis was pancreatic tumoue current[12]. Researchers involved in the determination of the gene expression of MMPs in lung cancer noticed the increased gene expression of MMP-2, MMP-3, MMP-8, MMP-9 and MMP-13. This increase does not correlate with the concentrations of enzymes obtained by zymography or ELISA methods on tissue homogenates or peripheral blood. This may suggest that cancerous tissue stimulates the production of metalloproteinases, whereas the body responds to the development of cancer by enhancing the synthesis of its inhibitors [13].

The results obtained for serum MMP-3 in this study coincide with the results from other researchers for other cancers. No increase in MMP-9 may be due to the too small study group and the very large spread of results obtained in the test. In the present study, the relationship was demonstrated between serum MMP-3 and histological malignancy (grading). The highest values were obtained in G1 patients. The explanation for these results may be the hypothesis that the induction of metalloproteinase production is caused by tumour cells without numerous mutations, which are still highly differentiated and able to activate growth factors. They stimulate the surrounding tissues to synthesize and secrete MMPs. With the decline in differentiation, this ability may disappear and therefore the concentration of MMP-3 in the serum decreases, but is still at a higher level than in the control group.

In recent years, the use of saliva in laboratory diagnostics has been of particular interest. The advantage is easy and non-invasive collection of this biological material. Many chemicals compounds, hormones and toxins can be identified in saliva. Also, metalloproteinases have been identified in this biological material. Popat et al. [14] in their studies assessed the concentration of MMP-1 and TIMP-1 in patients with periodontal disease. They showed significantly elevated values of metalloproteinase and decreased TIMP-1 values in the group of people with periodontitis. After patient recovery, they observed a decrease in MMP values and an increase in TIMP levels to those which were previously reported in the control group. Gonçalve et al. [15] studied changes in MMP-1, MMP-2, MMP-3, MMP-8, MMP-9, MMP-12 and MMP-13 values before and after treatment of periodontal lesions. They also showed higher values of MMPs in people with active inflammatory periodontal disease and their decrease after treatment. These data indicate the efficacy and reliability in the determination of MMPs in saliva and the ability to control the treatment process. Malignant diseases of the oral cavity are also characterized by an elevated level of metalloproteinases [16]. Shpitzer et al. [17] have shown that MMP-9 in the saliva of patients with cancer of the tongue was significantly higher than in healthy subjects, and that the increase in MMP-9 positively correlated with poor prognosis in patients. Ghallab and Shaker [18] analyzed MMP-9 in the saliva of patients with squamous cell carcinoma, precancerous lesions and healthy individuals. They showed that the highest concentrations of MMP-9 were found in participants with cancer, intermediate concentrations occurred with pre-malignant lesions, and the lowest were in healthy subjects. They concluded that MMP-9 may be considered as a biomarker which can be used for selecting groups with a high risk of cancer.

The presented study shows statistically higher levels of salivary MMP-3 in patients in the study group compared to healthy subjects. The average value of MMP-9 in saliva was lower in patients with cancer, but the spread of the results was high (5.4-1073.4 ng/ml). As a result, a statistical significance 
was not shown $(\mathrm{p}=0.0997)$. It was expected that throat cancer would have higher metalloproteinase concentrations than those derived from the larynx. Surprisingly, higher MMP-9 values were obtained for laryngeal tumours than for throat, while the mean for MMP-3 was similar for both tumour sites. However, these differences were not statistically significant.

In this study, higher serum concentrations of MMP-9 were observed in cigarette smokers and alcohol abusers with cancer; this differencewe was not detected in salivary MMP-9 levels. There was no relationship between smoking or alcohol consumption and MMP-3 concentration in patients with cancer (both in saliva and serum). The impact of cigarette smoking on the concentration of metalloproteinases has been the subject of only a few analyzes and did not affect all MMPs. Kim et al. [19] confirmed that tobacco smoke is responsible for the increased level of MMP-1, determined in the ELISA assay in fibroblasts derived from the human lung. Ozcaka [20] showed slightly different conclusions: MMP-9 concentration by ELISA in cigarette smokers was statistically higher than non-smokers, whereas such differences in MMP8 were not observed. This shows that not all MMPs are stimulated to grow in the case of exposure to tobacco smoke. Rukkumani et al. [21] observed increased MMP-9 activity in alcohol-rats. He stated that the elevated metalloproteinase level is the result of degenerative liver changes where there is an overproduction of collagen. Similarly, Banerjee [22] suggested that the growth of MMP-2, MMP-7 and MMP-9 during alcoholic liver damage is intended to protect against fibrosis and to aid in faster regeneration.

Knowledge of MMPs in tumours can be used in oncological therapy. Synthetic inhibitors of metalloproteinases have been available for several years. If it can be determined which MMPs are elevated in a particular cancer, it will be able to include their inhibitors in the treatment. This action will result in the inhibition of disease progression. Properly designed drugs are difficult to produce, but it is important to eliminate side-effects and keep them effective. Currently, dozens of compounds that have such effects have been developed and some of them are in clinical trials.

\section{CONCLUSIONS}

In the current study it was observed that the MMP-3 level was elevated in patients with throat and larynx cancer. These values were elevated both in saliva and in serum. There were no statistically significant differences in MMP-9 (saliva and serum) levels between the study and the control group. The size of the tumour and the involvement of lymph nodes have no influence on the concentrations of the metalloproteinases studied. However, with the decrease of the histological differentiation of a tumour, the level of MMPs decreases. In cigarette smokers and alcohol abusers, an increase of MMP9 in serum was reported. Effective treatment of throat and larynx tumours requires detailed knowledge of the factors that influence tumour growth. This study is another element that shows phenomena taking place at the cellular level during oncological disease. The increase in the value of this enzyme in the risk group may be used for early detection of tumor transformation and evaluation of treatment.

\section{REFERENCES}

1.Kołaczkowska E. Metaloproteinaza 9 (MMP-9) jako szczególny przedstawiciel metaloproteinaz macierzy zewnątrzkomórkowej: rola w napływie i apoptozie neutrofili w trakcie reakcji zapalnej. Postępy Biol. Kom., 2010; 2: 471-499.

2.Lipka D, Boratyński J. Metaloproteinazy MMP. Struktura i funkcja. Postepy Hig. Med. Dośw. 2008; 62: 328-336.

3. Fink K, Boratyński J. Rola metaloproteinaz w modyfikacji macierzy zewnątrzkomórkowej w nowotworowym wzroście inwazyjnym, w przerzutowaniu i w angiogenezie. Postepy Hig Med Dosw. 2012; 66: 609-628.

4. Deryugina EI, Quigley JP. Matrix metalloproteinases and tumor metastasis. Cancer Metastasis Rev. 2006 Mar; 25(1): 9-34.

5. Kawecki A, Nawrocki S i wsp. Nowotwory nabłonkowe narządów głowy i szyi. W: Zalecenia postępowania diagnostyczno-terapeutycznego w nowotworach złośliwych - 2013. Onkol. Prakt. Klin. Via Medica, Gdańsk, 2013: 2-32.

6. Wojciechowska U, Didkowska J. Zachorowania i zgony na nowotwory złośliwe w Polsce. Krajowy Rejestr Nowotworów, Centrum Onkologii - Instytut im. Marii Skłodowskiej - Curie. Dostępne na stronie http:// onkologia.org.pl/raporty/ dostęp z dnia 20.04.2017.

7. Rzewnicki I, Biszewska J. Epidemiologia raka krtani i gardła dolnego w latach 1988-2012 w materiale Kliniki Otolaryngologii Uniwersytetu Medycznego w Białymstoku. Otolaryngologia Polska, 2013; 67(6): 265-273.

8. Chun-Ying Wu, Ming-Shiang Wu, En-Pei Chiang, et al. Plasma Matrix Metalloproteinase-9 Level Is Better than Serum Matrix Metalloproteinase-9 Level to Predict Gastric Cancer Evolution. Clin Cancer Res. 2007 Apr; 13(7): 20542060.

9. Wilson S, Wakelam MJ, Hobbs RF, et al. Evaluation of the accuracy of serum MMP-9 as a test for colorectal cancer in a primary care population. BMC Cancer. 2006; 6: 258. doi:10.1186/1471-2407-6-258.

10. Merdad A, Karim S, Schulten HJ, Dallol A, Buhmeida, et al. Expression of matrix metalloproteinases (MMPs) in primary human breast cancer: MMP-9 as a potential biomarker for cancer invasion and metastasis. Anticancer Res. 2014 Mar; 34(3): 1355-66.

11. Jinga D C, Blidaru A, Condrea I i wsp. MMP-9 and MMP-2 gelatinases and TIMP1 and Timp-2 inhibitors in breast cancer: correlations with prognostic factors. J Cell Mol Med. 2006; 10: 499-510.

12. Yokoyama K, Kamata N, Fujimoto R, Tsutsumi S. Increased invasion and matrix metalloproteinase-2 expression by Snail-induced mesenchymal transition in squamous cell carcinomas. Int J Oncol. 2003 Apr; 22(4): 891-8.

13. Schütz A, Schneidenbach D, Aust G, Tannapfel A, Steinert M, Wittekind C. Differential expression and activity status of MMP-1, MMP-2 and MMP-9 in tumor and stromal cells of squamous cell carcinomas of the lung. Tumour Biol. 2002 MayJun; 23(3): 179-84.

14. Popat R, Bhavsar NV, Popat PR. Gingival crevicular fluid levels of Matrix Metalloproteinase-1 (MMP-1) and Tissue Inhibitor of Metalloproteinase-1 (TIMP1) in periodontal health and disease. Singapore Dent J. 2014 Dec; 35:59-64.

15. Gonçalves PF, Huang H, McAninley S, Alfant B, Harrison P, et al. Periodontal treatment reduces matrix metalloproteinase levels in localized aggressive periodontitis. J Periodontol. 2013 Dec; 84(12): 1801-8.

16. Luukkaa H, Klemi P, Hirsimäki P, Vahlberg T. Matrix metalloproteinase (MMP)7 in salivary gland cancer. Acta Oncol. 2010; 49(1): 85-90.

17. Shpitzer T, Hamzany Y, Bahar G, Feinmesser R, et al. Salivary analysis of oral cancer biomarkers. Br J Cancer. 2009 Oct 6; 101(7): 1194-1198.

18. Ghallab NA, Shaker OG. Serum and salivary levels of chemerin and MMP-9 in oral squamous cell carcinoma and oral premalignant lesions. Clin Oral Investig. 2016 May 10. [Epub ahead of print].

19. Kim H, Liu X, Kohyama T, Kobayashi T, et al. Cigarette smoke stimulates MMP1 production by human lung fibroblasts through the ERK1/2 pathway. COPD. 2004 Apr; 1(1): 13-23.

20. Ozçaka O, Biçakci N, Pussinen P, Sorsa T, et al. Smoking and matrix metalloproteinases, neutrophil elastase and myeloperoxidase in chronic periodontitis. Oral Dis. 2011 Jan; 17(1): 68-76. doi: 10.1111/j.1601082 5.2010.01705.x.

21. Rukkumani R, Priyanka A, Sankar P, Menon VP. Ferulic acid influences hepatic expression pattern of matrix metalloproteinases during alcohol and PUFA induced toxicity. Eur Rev Med Pharmacol Sci. 2012 Dec; 16(15):2147-53.

22. Banerjee P, Jana S, Chakraborty S, Swarnakar S. Inflammation and MMPs in alcohol-induced liver diseases and protective action of antioxidants. Indian J. Biochem Biophys. 2013 Oct; 50(5): 377-86. 